\title{
Do Hegemons distribute private goods?
}

\section{A Test of Power-Transition Theory}

\author{
Margit Bussmann \\ Department of Politics and Management \\ University of Konstanz, Germany \\ John R. Oneal \\ Political Science Department \\ University of Alabama, Tuscaloosa
}

\begin{abstract}
According to power-transition theory, war is most likely when the leading state is challenged by a rapidly growing, dissatisfied rival. Challengers are said to be dissatisfied because the hegemon manages the status quo for its own benefit, rewarding its allies and penalizing rivals. We assess the leading state's ability to distribute the private goods of peace, victory in war, and economic prosperity. States with alliance portfolios similar to the hegemon's are not protected from aggression; nor do they grow more rapidly than countries with which the leading state is not closely allied. The dominant power's allies are more apt to win defensive wars, although the means by which this is accomplished are unclear. On balance, our results call into question the ability of the leading state to engineer satisfaction by distributing private goods. Like hegemonic-stability theory, power-transition theory exaggerates the influence of the leading state over the international system.
\end{abstract}

Keywords: power-transition theory; hegemonic-stability theory; hegemon; international alliance

$\mathrm{T}$ wo influential schools of thought in international relations argue that a dominant state provides important benefits to the international system by substituting to a degree for world government. According to hegemonic-stability theory, the leading state maintains the peace and provides other public goods (e.g., a stable currency and an open trading system) necessary for the smooth functioning of the world economy (Kindleberger 1973; Krasner 1976; Keohane 1980; Gilpin 1981). What is distinctive about this theory is not the argument that a powerful state can impose an international

\footnotetext{
Authors' Note: Earlier versions of this article were presented at the 2002 annual meeting of the European Public Choice Society and at the 2004 annual meeting of the International Studies Association. We thank Jonathan DiCicco, Kelly Kadera, Alan Lamborn, Erich Weede, and Ekkhart Zimmermann for helpful comments. Our data and Stata do-files are posted at http://jcr.sagepub.com/cgi/content/full/51/1/88/DC1/.
} 
regime but the claim that all states generally benefit from the hegemon's provision of public goods (Snidal 1985). Indeed, the hegemon is thought to solve the problem of collective action at relatively high cost to itself because of free riding. There is "a surprising tendency for the "exploitation' of the great by the small" (Olson 1971, 3; also Kennedy 1988; Oneal and Diehl 1994; Sandler and Hartley 1999).

Power-transition theory, developed by three generations of scholars (Organski 1968; Organski and Kugler 1980; Kugler and Lemke 1996; Kugler and Lemke 2000; Tammen et al. 2000; Kadera 2001; Lemke 2002), also emphasizes the leading state's ability to influence international outcomes, but it offers a different explanation for the widespread peace that should result from its preponderance of power: The dominant state prefers peace to enjoy the economic benefits of the international system it organized, but it is expected to be more discriminating in the distribution of the benefits created by its power. To maintain the status quo efficiently, it co-opts the aid of powerful allies and distributes to them private goods-benefits it denies to rivals and states too weak to affect the international balance of power. The leading state is not expected to provide public goods (Lemke 2004). A major war is likely when a rapidly growing, dissatisfied contender challenges the dominant state in hopes of reconfiguring the world order so that its interests will be served. Thus, hegemonicstability theory and power-transition theory agree that international peace is most likely when the leading state has a preponderance of power, but they disagree about whether the leader creates primarily public or private goods. This leads to further disagreement regarding whether the hegemon is exploited by smaller states' free riding or benefits disproportionately from the international system that it was instrumental in creating.

Efforts to assess the hegemon's provision of public goods have produced mixed results for hegemonic-stability theory (Keohane 1984; Webb and Krasner 1989; Spiezio 1990; Peet 1992; Mansfield 1994; Oneal and Diehl 1994; Pollins 1996; Russett 1985; Sandler and Hartley 1999; Russett and Oneal 2001; Sacko 2003; Bennett and Stam 2004). Whether the leading state provides private goods-a central proposition in power-transition theory-has rarely been investigated. Here, we perform several tests. If the theory is correct, the dominant state should be able to engineer satisfaction within the international system, rewarding its friends for supporting the status quo and punishing its adversaries. Aristotle believed that people desire peace, glory, and prosperity. Consequently, we assess the leading state's ability to provide and deny these benefits using established models of the initiation of fatal militarized disputes, the outcome of wars, and economic growth.

To anticipate our results, we find only limited support for the claim that the leading state can shape the international system to its benefit and distribute private goods. The leader and its allies are not protected from others' initiating the use of force against them; nor do they grow more rapidly economically. The leading state and its close allies do fare better in defensive wars than other states, an important outcome; but how the hegemon produces this result is unclear. These results, taken 
together with previous empirical research on hegemonic-stability theory, call into question the widespread belief that the leading state exercises hegemonic influence in international affairs-a finding of particular importance in the post-cold war era.

In the next section, we briefly summarize power-transition theory. This is followed by closer consideration of the important theoretical role played by states' satisfaction with the status quo. We show how the dominant state is thought to use private goods to increase the satisfaction of its allies to secure their support. Next, we specify regression models that allow us to determine whether the hegemon and its allies enjoy freedom from aggression, favorable military outcomes, and greater economic success than do other states. We conclude by discussing the implications of our results.

\section{Power-Transition Theory}

Power-transition theory is constructed on three fundamental claims (Kugler and Lemke 2000): the internal growth of nations influences international politics, world politics is characterized by hierarchy rather than anarchy, and relative power and evaluations of the international status quo are important determinants of interstate wars. From its earliest formulation, Organski (1968) emphasized the implications of national economic and political development for interstate relations in the modern era. Industrialization and the growing effectiveness of the state increase a nation's power and change its behavior internationally. The countries that industrialized first came to dominate the international system in the eighteenth and nineteenth centuries, but later modernizers periodically challenged the status quo. This emphasis on the international implications of domestic development sets power-transition theory apart from most realist writings, which typically take a more static view of nations' power.

An even more striking difference with conventional realism is the emphasis power-transition theory places on the hierarchical—rather than anarchic—character of world politics. Organski (1968) likened the international system to a pyramid with the most powerful state at the apex and major, middle, and minor powers arrayed below. Relations among these states are anarchic in the literal sense that there is no world government, but the international system is not chaotic. The international system is hierarchical because the dominant state established and maintains it, creating patterns in states' political, military, and economic relations and in "the distribution of value" (Kugler and Lemke 2000, 131). The leading state "orders, adjusts, and allocates" (Siverson and Miller 1996, 59), and it "always benefits disproportionately from any enterprises involving less powerful states, be they friends or foes" (Organski 1968, 358). Thus, power-transition theorists adopt the traditional view of the powerful: they use their power to promote their interests. The dominant state maintains a stable international order because it is the principal beneficiary of peace. 
To serve its interests, the hegemon enlists the support of other powerful states. ${ }^{1}$ Despite its great capabilities, it cannot control potential rivals by itself or cannot control them as efficiently, so the leading state constructs a defensive security systema status quo alliance system (Tammen et al. 2000, 33) designed to maintain the advantageous global order it created after the last great war (Organski 1968; Gilpin 1981). To be successful, a number of great and middle powers must be attracted to the hegemon's side. Powerful states are courted because they can provide valuable support. The dominant state maintains the status quo by "managing the international system under rules that benefit its allies and satisfy their national aspirations" (Tammen et al. 2000,6). A few states at the top, more in the middle, and most at the bottom of the hierarchy are excluded from the hegemon's alliance system and are consequently dissatisfied with the existing distribution of value. ${ }^{2}$ Power-transition theory argues that alliances tend to be fixed while traditional realism sees shifting commitments as a crucial mechanism for maintaining the balance of power.

The danger of a major war does not come from small states-whether dissatisfied or not—or from powerful, satisfied ones. Small states cannot effectively challenge the status quo, and the dominant state's powerful allies have limited incentive to do so. "These nations are satisfied with the present international order and its working rules, for they feel that the present order offers them the best chance of obtaining the goals they have in mind"; they have "their rightful share of benefits" (Organski 1968, 366). It is a powerful, dissatisfied state that threatens the peace, for it has both the opportunity and the willingness to initiate conflict (Starr 1978). Usually such states have come to power after the current order was established and the distribution of benefits determined. They seek to restructure the system to receive benefits commensurate with their newly acquired power. Consequently, the prospect of a great war grows as a powerful dissatisfied challenger overtakes the hegemon.

The dominant nation can anticipate such a challenge and will use its power over the international distribution of value in an attempt to preserve its privileged position. It can, for example, delay the rival's growth by imposing trade barriers and embargoes, refusing to provide aid, and supporting discriminatory action in international organizations (Lemke 2002, 22-27; Lemke 2004). The leading state directs sanctions toward and benefits away from threatening states. Control over the distribution of private goods is, according to power-transition theory, important in supplementing deterrence in the hegemon's efforts to maintain the status quo.

Originally, the danger of war was thought to be influenced by the speed with which the challenger overtook the leader; but Kim and Morrow (1992) and recently Bennett and Stam (2004) found little support for this proposition. As a consequence, Lemke and Kugler (1996) have suggested that power-transition theory should be called "power-parity theory." ${ }^{3}$ Indeed, there is abundant empirical evidence that a preponderance of power increases the prospects for peace between two states (e.g., Organski and Kugler 1980; Kim 1991, 1992, 1996; Kim and Morrow 1992; Geller 
1992; Vasquez 1993; Kugler and Lemke 1996; Lemke and Werner 1996; de Soysa, Oneal, and Park 1997; Oneal, Russett, and Berbaum 2003; Reed 2003; Sweeney 2003; Hegre 2004; Bennett and Stam 2004). In the tests reported below, we assess whether the leading state is able to extend or deny the pacific benefit of its great power to others.

To summarize, power-transition theory portrays the international system as significantly hierarchical and only "conditionally anarchic" (Lemke and Reed 1998). The dominant state, following early industrialization and victory in a major war, establishes an international order of which it is, by design, the principal beneficiary. It maintains and directs the system by virtue of its preponderant position and by co-opting other powerful countries into a stable network of defensive alliances. The hegemon enlists the support of these states and rewards their cooperation by distributing private goods. The leading state also engineers states' satisfaction by denying benefits to potential challengers. In short, "[s]ome states will benefit from the existing status quo and others will not" (Lemke 2004, 56). A major war is likely when a dissatisfied nation achieves parity with the hegemon and seeks to modify this distribution of value.

\section{The Distribution of Benefits}

Because conflict is expected only when a powerful state is dissatisfied, the determination of states' attitude toward the status quo is central to tests of power-transition theory. Early assessments did not, however, incorporate this feature. Organski and Kugler (1980), for example, explained wars among the contenders by reference only to their power. It was simply assumed that different evaluations of the status quo explain why the transition between Germany and Great Britain led to World War I, whereas the growth of the United States at about the same time was peacefully accommodated. ${ }^{4}$ Proponents of the theory acknowledge that the influence of states' evaluations of the status quo must be assessed systematically (Kugler and Lemke 1996; Siverson and Miller 1996; Lemke 2002). It is also important to identify explicitly the benefits that accrue to the leading state and its supporters but are denied by them to potential challengers (Oneal, de Soysa, and Park 1998; DiCicco and Levy 1999, 2003). Ultimately, the distribution of these private goods determines the satisfaction of states and is the key to explaining why some power transitions end in war and others do not (Vasquez 1996).

Kim (1991, 1992; Kim and Morrow 1992) was among the first to incorporate a measure of states' evaluations of the status quo in testing the theory. A state's satisfaction with the international system can be measured, he proposed, by the similarity of its alliances with the security portfolio of the hegemon-an insight drawn from Bueno de Mesquita (1981), who used the similarity of alliance portfolios to gauge states' 
utility for war. States that establish security agreements with the hegemon and its allies and that avoid alliances with the countries it shuns are likely to have similar foreign policies and share preferences regarding important issues (Lemke 2002, 100). Such states "should think about international affairs and act in international matters in ways similar to the dominant power" (Kugler and Lemke 2000, 137). Indeed, Kim's research indicates that evaluations of the status quo are more important than the distribution of power in explaining interstate conflict-a view reinforced by some recent research (Lemke and Werner 1996; Lemke 2002; Sacko 2003).

Scholars have employed other measures of satisfaction-the money-market discount rate (Bueno de Mesquita 1990) or extraordinary military buildups (Werner and Kugler 1996)_but the similarity of alliance portfolios is most appropriate because power-transition theory emphasizes the role that powerful allies play in helping the dominant state manage the international system. Alliances are "stable coalitions of states with similar evaluations of the status quo" (Tammen et al. 2000, 33), leading Lemke and Reed $(1996,149)$ to conclude that the similarity of alliance portfolios is "a valid general indicator of status quo evaluations." 5

Although the similarity of alliance portfolios is theoretically justified and a widely used measure of satisfaction (Lemke and Reed 1996, 1998; Bueno de Mesquita 1996; Lemke 2002; Bennett and Stam 2004), it is not a direct assessment of the benefits states receive. We need to know, as Lemke $(2002,33)$ has asked: "How are satisfied states 'benefited' by the status quo, and how are dissatisfied states 'harmed' by the status quo?" Early statements of power-transition theory offer little guidance (Siverson and Miller 1996); but without answering these questions, it is difficult to "convincingly identify dissatisfied states or demonstrate that the dominant power has constructed an international order that gives it disproportionate advantage" (DiCicco and Levy 1999, 690).

What private goods might a hegemon distribute? Siverson and Miller (1996) echo Aristotle regarding the appeal of peace, glory, and prosperity. States that are satisfied, they say, should receive "security, access to resources, trade advantages, and even something so simple as deference from other states" (p. 59). Kugler and Lemke $(2000,131)$, too, conclude that "to be advantaged by the status quo means one's state will be richer, more prestigious, more secure than it otherwise would be." In short, the leading state seeks to increase its support among its allies by providing both economic and security goods (Tammen et al. 2000, 9; also Russett 1985).

Peace is the most obvious benefit that should accrue from being integrated into the dominant state's system of alliances. Power-transition theorists expect that the leading state will generally suppress conflict because peace best allows it to advance its interests. This may explain why hegemons have not initiated preventive wars against rising challengers (Tammen et al. 2000, 27) — a persistent theoretical puzzle. Indeed, Lemke and Reed (1996) sought to subsume the democratic peace under power-transition theory, arguing that democracies do not fight because they are 
satisfied in an international system created and maintained by democratic hegemons: Great Britain from 1815 through World War II and the United States afterwards. It is joint satisfaction, not democracy per se, they argued, that leads to peace. Subsequently, however, Russett and Oneal (2001) showed that joint satisfaction does not account for democracies' peaceful relations: the likelihood of a militarized dispute is strongly influenced by states' political regimes but unrelated to their satisfaction with the status quo.

Certainly, power-transition theory leads to the expectation that the leading state will protect its allies from aggression and be of material benefit if war is forced on them. With the direct support of the dominant state and its rallying of others in its defensive coalition, close allies should be able to deter attack and win the defensive wars they fight, providing them deference and glory. They should generally be disinclined to initiate disputes so that they and the hegemon can enjoy the economic benefits of the status quo, although some allies might have a sense of entitlement and be emboldened by their association with the hegemon to act aggressively. It is unclear whether the leading state's allies should be able to count on its support in wars they initiate. The hegemon is said to prefer peace (Tammen et al. 2000) and may not support aggressive behavior, but it may be forced to come to the aid of its allies even when they act aggressively to protect its reputation and their capabilities.

The leading state should also be able to influence the distribution of economic value internationally. Access to resources, trade advantages, and security-the benefits mentioned by Siverson and Miller (1996) - should promote growth and prosperity. A growing economy is inherently desirable and increases national capabilities (Organski 1968; Tammen et al. 2000, 35-6). The United States has been active in the Bretton Woods institutions and in various regional economic organizations "to provide economic benefits that enhance satisfaction within the dominant country's coalition" (Tammen et al. 2000, 27). During the cold war, the United States sought to retard the growth of the Soviet Union and its allies through such agencies as the Coordinating Committee for Multilateral Export Controls (Lemke 2002, 22ff.; Lemke 2004), but apt historical examples are not sufficient to prove that the leading state engineers satisfaction in the international system, as Lemke $(2002,33)$ has acknowledged.

To summarize, some states are said to be dissatisfied with the international system because the dominant state especially and its allies benefit disproportionately from the status quo. Proponents of power-transition theory have not shown in social scientific analyses, however, that close association with the leading state actually leads to private gain. This is a significant weakness. Indeed, DiCicco and Levy (2003) conclude that clarification regarding the sources of states' satisfaction is necessary for continued progress within the power-transition research program. We now provide three tests of whether the leading state engineers satisfaction through the distribution of private goods. 


\section{Research Design}

We assess the leading state's ability to distribute the private goods of peace, victory in war, and economic growth by adding a measure of states' satisfaction with the status quo to established models of the initiation of fatal militarized disputes, the outcome of wars, and economic growth. Our gauge of satisfaction is the similarity of a country's alliance portfolio with that of the hegemon, as measured by Signorino and Ritter's (1999) $S$. This measure of association is adjusted for national capabilities, weighting more powerful states more heavily, and takes into account only the states in the appropriate subregions, as Signorino and Ritter recommend. We do not use Kendall's $\tau_{b}$ coefficient (Bueno de Mesquita 1981; Kim 1991) because it is appropriate only for measuring the association of ranked categorical data. These data are from EUGene (Bennett and Stam 2000); other data are taken from the sources of our models. Until 1945, Great Britain was the hegemon and from 1946 onward, it was the United States. In the remainder of this section, we discuss our three models. We present our results in a subsequent section.

\section{A Model of the Initiation of Fatal Disputes}

To determine if the leading state is able to secure peace for itself and its allies, we use logistic regression analyses of directed dyads, considering all pairs of states, from 1885 to 2001, for which data are available. Each state is paired twice with every other state in the system in each year, once as the focal state that might use military force against the other and once as the potential target of such action. Our regression model, drawn from Oneal (2006; Oneal and Tir 2006), includes the political character of the focal state and the target, the degree to which the focal state is economically dependent on the potential target, whether the states are allied, the balance of power from the focal state's perspective, whether the states share a common border, the distance separating them, and whether the focal state is a major power. We correct for temporal dependence by controlling for the time elapsed since the last initiation and adjust for the rapid growth in the number of states in the international system.

We identify the initiations of fatal militarized interstate disputes, using the Correlates of War (COW) data prepared by Maoz (1999; Bennett and Stam 2000). An initiator is a state that was involved in a conflict from its inception and threatened or used military force against a target state. A fatal dispute is a conflict in which at least one member of the armed forces of the parties to the hostilities was killed. The dependent variable equals one if the focal state initiated a fatal dispute against a target in a year and zero otherwise.

To test power-transition theory, we include the $S$ measure of satisfaction with the status quo for both the focal state and the target in each dyad. If the leading state provides protection from attack to closely allied states, the estimated coefficient for potential targets' satisfaction will be negative. The expected sign of $S$ for the focal 
state is also negative. States favored by the status quo should, like the hegemon, prefer peace so that they can enjoy the benefits of the international system, and the hegemon should reinforce this peaceful inclination to advance its own interests. As noted earlier, however, it is possible that states closely associated with the leading power or the leading state itself will be emboldened to initiate disputes because they anticipate the support of their powerful allies, in which case $S$ for the focal state would have a positive coefficient.

Oneal (2006) uses the Polity III data to assess the political character of regimes, noting which states were coherent democracies, autocracies, or "incoherent" regimes (Jaggers and Gurr 1995) and using these designations to identify the nine possible types of directed dyads: democracy $\rightarrow$ democracy, democracy $\rightarrow$ mixed regime, democracy $\rightarrow$ autocracy, autocracy $\rightarrow$ democracy, autocracy $\rightarrow$ mixed regime, and so on. The results of his tests confirm that the initiation of force is conditional on the character of both the focal state's and the target's political institutions (Oneal and Russett 1997). ${ }^{6}$ Relative to the autocracy $\rightarrow$ autocracy reference group, only the estimated coefficients for the democracy $\rightarrow$ democracy and autocracy $\rightarrow$ democracy indicators proved to be significantly different from zero.

Both results show the greater peacefulness of democratic states. They are unlikely to initiate disputes against one another, and the conflict characteristic of autocracies and democracies is due primarily to the aggressiveness of the autocracies: democracies are no more likely to target autocracies than are other autocracies. ${ }^{7}$ Given the insignificance of six of the eight dyadic indicators, we include just the democracy $\rightarrow$ democracy and autocracy $\rightarrow$ democracy variables in the analyses presented below. This simplification does not affect the results of our tests. The two dyadic indicators and all other right-side-side variables are lagged one year to ensure that they are not affected by a dispute that is to be explained. Thus, conditions in year $t-1$ account for militarized disputes initiated in year $t$.

To measure a state's dependence on trade with its dyadic partner in the post-1949 period, we use Gleditsch's (2002) latest data. For earlier years, the data are drawn from the League of Nations for the interwar period and The Statesman's Yearbook (Epstein 1913) for the pre-World War I era. Since trade is expected to influence a state's actions only if it is economically (and hence politically) important, the sum of a country's exports and imports with its partner is divided by its gross domestic product (GDP). Gleditsch has assembled this information for the years after 1949, and Maddison (1995) is the source for earlier years (Russett and Oneal 2001). The more economically dependent one state is on another, the less likely is the use of force. (Russett and Oneal 2001; Mansfield and Pollins 2003; Schneider, Barbieri, and Gleditsch 2003; Oneal 2006).

Realists emphasize the importance of the balance of power and alliances in shaping interstate relations. As proponents of power-transition theory have argued, the weight of the evidence (e.g., Oneal, Russett, and Berbaum 2003; Bennett and Stam 2004) indicates that it is preponderance that deters military action; therefore, the risk 
that a state will initiate a use of force should increase as the capability ratio approaches 1.0 (when the two states are equally powerful) and then decline (Bennett and Stam 2004; Hegre 2004; Oneal 2006). To capture this curvilinear relationship, the regression model includes the logarithm of the capability ratio and its square, where the capability ratio equals the focal state's military capability index divided by that of its potential target. The inverted-U curve that is expected would be indicated by a positive coefficient for the capability ratio and a negative one for its square. Allies are generally thought to fight each other less than other states because they share extensive interests (Senese and Vasquez 2005). We control for this influence using the appropriate indicator.

The potential for interstate violence exists when one member of a dyad can reach the other with military force. For most states, this is largely determined by geographic proximity. Distance reduces the capability to fight and most of the incentives to do so as well (Boulding 1963; Stinnett et al. 2002). We include two terms in our regressions to capture the influence of geographic proximity. Contiguity equals 1 if two states are directly contiguous or 0 if they do not share a land boundary and are separated by more than four hundred miles of water. The presence of a border dramatically increases the risk of fighting - over the boundary itself, natural resources, irredentist sentiments, and so on. Distance is the natural logarithm of the great circle distance between states' capitals. Its inclusion distinguishes states in the same region from those more distant. The two measures of proximity are only moderately correlated. The constraining influence of geographic proximity is least for powerful states. To control for the ability to initiate conflict, Oneal (2006) therefore identifies the major powers using a binary indicator.

To control for duration dependence, Oneal (2006) created a variable that marks the number of years of peace since a state last initiated a fatal dispute against its dyadic partner and generated a natural cubic spline with three interior knots (Beck, Katz, and Tucker 1998; Tucker 1999). We also correct for the change in the probability of dyadic conflict because of the increasing number of states in the international system over time. This violation of an assumption underlying regression analysis is greatest for the noncontiguous, minor powers; therefore, we include a variable (system size) that equals the natural logarithm of the number of states in the system, as Raknerud and Hegre (1997) recommend; it is 0 otherwise.

\section{A Model of War Outcomes}

To determine whether the hegemon and its close allies are more likely to prevail in conflict when it occurs, we rely on a model of war outcomes developed by Reiter and Stam (2002). Their data include observations of nations that had concluded a war between 1816 and 1990. The dependent variable measures whether a country won or lost; draws were dropped from the analysis. Again, we use logistic regression analysis. If states with alliance portfolios similar to that of the leading state are more likely to win the wars they fight, the estimated coefficient of $S$ will be positive. 
Included among Reiter and Stam's (2002) explanatory variables is an indicator identifying the initiator of the war, who is expected to win. To analyze the link between regime type and the outcome of wars, they use two interactive variables that take into account the nature of the political systems of the initiator of conflict and the target. The interaction for the initiator consists of two fractional polynomial terms designed to test their proposition relating regime type to victory: democratic initiators are most likely to win, followed by dictatorships, with initiators with mixed regimes having the highest propensity to lose a war. For the target, the interaction with the Polity score tests Reiter and Stam's war-fighting explanation of military success: democracies are more likely to win defensive wars ceteris paribus because of their greater effectiveness on the battlefield.

Reiter and Stam (2002) include in their model several realist variables, of which some are directly relevant to our study because they could be channels through which the dominant state secures victory for itself and its allies. First, the hegemon and its allies should generally be more powerful than their opponents. The size of a state's military and industrial capabilities relative to its adversaries is measured using the COW composite capabilities index. Second, separate from its own strength, a state can more or less reliably count on material support from its allies. For states with close ties to the hegemon, this would include not only the leading state but also other powerful states in its security system. Reiter and Stam enter the contributions of alliance partners separately into the equation, measuring this relative to the capabilities of all war participants. Third, the quality of a country's troops, measured as spending per soldier compared to its adversary's, should also influence the outcome of a war. The allies of the leading state may benefit from the dominant state's advanced technology and training. In the analyses reported below, we consider whether these are important pathways by which the leading state influences the outcome of wars.

Based on the Encyclopedia of Military History and other sources, Reiter and Stam (2002) code dummy variables to take into account military strategy, distinguishing between maneuver, attrition, and punishment strategies, and whether the political goals of a state are offensive or defensive. Closely related to these strategic alternatives is a variable that captures the influence of terrain; this is interacted with a ranking of the various strategies. Reiter and Stam (2002) can be consulted for details regarding their data and the theoretical expectations that inform the specification of their regression model.

\section{A Model of Economic Growth}

Our baseline model of growth is drawn from Barro (1996), and Barro and Lee (1994) are the source of our data, which are comprised of five-year panels from 1960 to 1990 . The dependent variable is the growth rate of a nation's real GDP per capita in 1985 international prices over a five-year period. Power-transition theory leads us to expect that the United States and its close allies grew more rapidly in this period 
of American hegemony than they would otherwise have done because of preferential trading arrangements, favorable relations with U.S. commercial and financial institutions, favorable treatment in the International Monetary Fund and World Bank, and so on. Neutral countries and adversaries of the United States should have done less well economically. Detailed economic data for the years before World War II, the period of British dominance, are unavailable.

Barro's (1991, 1996, 2000) economic analysis begins with a key insight from neoclassical economics: poor countries are expected to grow more rapidly and to converge on more advanced countries because there are declining marginal returns to investment, and investors seek to maximize their profits (Solow 1956). Thus, his model of growth includes a measure of each country's level of development at the start of the period over which growth is measured. Models of endogenous growth, on the other hand, acknowledge that poor states do not necessarily grow faster than rich states because they may have adopted bad economic policies (Lucas 1988; Romer 1990). Endogenous theories emphasize that economic performance is influenced primarily by the nature of a country's economic and political system, not external forces such as technological change, as in neoclassical models. ${ }^{8}$

Lucas (1988) stressed the importance of human capital in particular. A poor country with low levels of human capital will remain poor. This is the so-called underdevelopment trap (Barro 1989). Investment will not speed growth if workers are poorly educated, unhealthy, or subject to discrimination. Our measure of human capital incorporates several components: (1) the average years of secondary schooling in the population over age twenty-five, (2) the average years of higher schooling in the population over age twenty-five, (3) the logarithm of the total fertility rate, measured as children per woman, and (4) the logarithm of life expectancy at birth. The average years of secondary and higher schooling indicate the level of education in the society. Life expectancy is a proxy for public health, and the fertility rate is an indication of population growth and the rights of women. The correlations among the four measures range from .61 to .80; therefore, combining them into a single measure is appropriate and eliminates the problem of collinearity that would arise if these variables were used individually (de Soysa and Oneal 1999). We used principal components factor analysis to create this index of human capital.

In modeling economic growth, following Barro (1989, 1991, 1996, 2000), we control for the size of government. Barro extends the endogenous model by introducing the effects of governments' policies on growth rates. Governmental expenditure can enhance growth if it provides important public goods, namely human capital or the protection of property rights, but governmental consumption lowers savings, adversely affecting productivity growth and income. Governmental consumption equals the ratio of government's real expenditures, net of spending on defense and on education, to real GDP. In addition, the black market exchange-rate premium is included in our economic model to account for governmental policies that distort markets. It is the ratio of the black market exchange rate to the official rate minus 1 (Barro 1996). 
Investment is essential for economic growth and is a core variable in models of growth (Levine and Renelt 1992). We include in our analysis the ratio of real domestic investment (private plus public) to real GDP. In addition, we take into consideration change in the terms of trade, which indicates the purchasing power of a country's exports. Improving terms of trade, that is, export prices that are rising faster than import prices, stimulate domestic output (Barro 1996). Change in the terms of trade is measured as the growth rate of export prices minus the growth rate of import prices.

\section{Results}

In our first test of power-transition theory, we determine whether a hegemon deters potential adversaries from initiating fatal militarized disputes against its close allies, using logistic regression analyses of directed dyads, 1885 to 2001 (see Table 1). The results for the baseline model in column 1 are consistent with those reported by Oneal (2006; Oneal and Tir 2006). The estimated coefficients for the democracy $\rightarrow$ democracy and the autocracy $\rightarrow$ democracy dyads indicate, as expected, that democracies are unlikely to start a dispute with another democracy but that autocracies are prone to target democratic states. This support for the democratic peace is consistent with other analyses of directed dyads as well (Bueno de Mesquita and Ray 2004; Hegre 2004; cf. Bennett and Stam 2004). There is also clear support for the liberal view that economic interdependence reduces conflict. The capability ratio and its square are statistically significant individually and jointly $(p<.01)$. The signs of their estimated coefficients indicate that the likelihood of conflict increases as the capability ratio approaches 1.0 , when power is evenly distributed within a dyad, and then declines (Hegre 2004; Bennett and Stam 2004). If either the focal state or the target holds a preponderance of capabilities, the use of force is unlikely. Indeed, the likelihood of an initiation is remarkably symmetrical around the point at which power is evenly balanced (Oneal 2006). Interestingly, the initiation of a fatal dispute is most likely when the focal state is somewhat weaker than the target.

The alliance indicator is clearly insignificant $(p<.40)$-a result difficult to reconcile with the emphasis that Senese and Vasquez (2005) place on the pacifying benefit of alliances in their account of the steps to war. The other variables in the equation perform as expected. Distance makes the initiation of a fatal dispute less likely, while the existence of a shared border increases the probability that a conflict will occur. Major powers are more likely to initiate a dispute than other states, a long period without a fatal dispute is a good predictor of continued peace, and the probability of conflict for a particular pair of noncontiguous, minor powers has declined as the number of states in the system has increased.

In the second column of Table 1, we provide the simplest possible test of powertransition theory, using only the measure of a state's satisfaction with the status quo for both the focal state and the potential target. Ray (2005) suggests looking first at 
Table 1

Logistic Regression of the Initiation of Fatal Militarized Interstate Disputes, 1885-2001

\begin{tabular}{|c|c|c|c|c|}
\hline & (1) & (2) & (3) & (4) \\
\hline & $\begin{array}{c}\text { Fatal } \\
\text { Initiation }\end{array}$ & $\begin{array}{c}\text { Fatal } \\
\text { Initiation }\end{array}$ & $\begin{array}{c}\text { Fatal } \\
\text { Initiation }\end{array}$ & $\begin{array}{c}\text { Fatal } \\
\text { Initiation }\end{array}$ \\
\hline Satisfaction with status quo (focal state) & & $\begin{array}{l}-0.602 * * \\
(0.227)\end{array}$ & $\begin{array}{c}-0.420^{\dagger} \\
(0.220)\end{array}$ & $\begin{array}{c}-0.022 \\
(0.228)\end{array}$ \\
\hline Satisfaction with status quo (target state) & & $\begin{array}{c}-0.405^{*} \\
(0.185)\end{array}$ & $\begin{array}{c}-0.193 \\
(0.184)\end{array}$ & $\begin{array}{c}0.102 \\
(0.214)\end{array}$ \\
\hline Democracy $\rightarrow$ democracy & $\begin{array}{c}-1.001^{*} \\
(0.435)\end{array}$ & & & $\begin{array}{c}-1.020^{*} \\
(0.426)\end{array}$ \\
\hline Autocracy $\rightarrow$ democracy & $\begin{array}{c}0.584^{*} \\
(0.256)\end{array}$ & & & $\begin{array}{r}0.552^{\dagger} \\
(0.295)\end{array}$ \\
\hline Economic dependence (focal state) & $\begin{array}{r}-12.209^{\dagger} \\
(6.485)\end{array}$ & & & $\begin{array}{r}-12.491^{*} \\
(6.563)\end{array}$ \\
\hline $\ln$ (capability ratio) & $\begin{array}{c}0.756^{*} \\
(0.322)\end{array}$ & & & $\begin{array}{c}0.755^{*} \\
(0.323)\end{array}$ \\
\hline $\ln (\text { capability ratio })^{2}$ & $\begin{array}{l}-0.042^{* *} \\
(0.016)\end{array}$ & & & $\begin{array}{l}-0.042^{* * *} \\
(0.016)\end{array}$ \\
\hline Allies & $\begin{array}{c}-0.203 \\
(0.181)\end{array}$ & & & $\begin{array}{c}-0.207 \\
(0.180)\end{array}$ \\
\hline Contiguity & $\begin{array}{l}1.500 * * \\
(0.468)\end{array}$ & & $\begin{array}{l}4.750 * * \\
(0.231)\end{array}$ & $\begin{array}{l}1.488 * * \\
(0.484)\end{array}$ \\
\hline $\ln ($ distance $)$ & $\begin{array}{c}-0.345^{* *} \\
(0.095)\end{array}$ & & & $\begin{array}{l}-0.346^{* *} \\
(0.095)\end{array}$ \\
\hline Major power & $\begin{array}{c}0.755^{*} \\
(0.335)\end{array}$ & & & $\begin{array}{l}0.751^{* *} \\
(0.335)\end{array}$ \\
\hline System size & $\begin{array}{l}0.656^{* *} \\
(0.099)\end{array}$ & & & $\begin{array}{l}0.659 * * \\
(0.099)\end{array}$ \\
\hline Years of peace & $\begin{array}{c}-0.409^{* *} \\
(0.041)\end{array}$ & & & $\begin{array}{c}-0.410 * * \\
(0.041)\end{array}$ \\
\hline Constant & $\begin{array}{c}-5.033^{* *} \\
(1.807)\end{array}$ & $\begin{array}{c}-7.934 * * \\
(0.114)\end{array}$ & $\begin{array}{c}-9.730^{* *} \\
(0.197)\end{array}$ & $\begin{array}{l}-5.002 * * \\
(1.818)\end{array}$ \\
\hline Pseudo $R^{2}$ & .34 & .01 & .25 & .34 \\
\hline Observations & 915,291 & 915,517 & 915,517 & 915,291 \\
\hline
\end{tabular}

Note: Robust standard errors in parentheses. Estimated coefficients for three peace-years splines not reported in table.

${ }^{\dagger}$ significant at $10 \%$. * significant at 5\%.** significant at $1 \%$.

such a spare specification. As discussed earlier, the estimated coefficient of $S$ for the target should be negative because the leading state is expected to protect its close allies from attack. Close association with the hegemon should also be negatively associated with the initiation of violence. Indeed, both coefficients are negative and statistically significant. 
This support for power-transition theory is not even minimally robust, however. In column 3 , we report a test with just the measure of contiguity added. Now the satisfaction of the potential target is unrelated to the likelihood of initiation $(p<.30)$, while the coefficient of $S$ for the focal state is significant at the .06 level. In a test not reported in the table, both measures of satisfaction were clearly insignificant when proximity, major-power status, the years of peace, and the size of the international system were held constant. These influences are antecedent to satisfaction and should be included as minimal controls (King 1991; Oneal and Russett 2005).

In the fourth column of Table 1, we add both measures of satisfaction to the baseline model in column 1. Again, the coefficient of the potential target's satisfaction with the status quo is insignificant $(p<.63)$. The hegemon and its close allies are no less likely ceteris paribus to be the targets of the use of force than are other states. This finding is consistent with the nondirected dyadic analyses of Russett and Oneal (2001). ${ }^{9}$ The sign of the focal state's, or potential initiator's, measure of satisfaction is also insignificant $(p<.93)$. States closely allied with the leading state neither refrain from aggressive action to enjoy the benefits of the status quo, nor take advantage of the backing of their powerful allies to act forcefully. ${ }^{10}$

In the next series of tests, we examine whether the leading state helps its close allies win the wars they fight. In Table 2, we first estimate the baseline model drawn from Reiter and Stam (2002). ${ }^{11}$ The two polynomial interactions of politics and initiation are significant individually, although jointly they are marginally insignificant $(p<.16)$. These results tend to support the view that selection effects are important in accounting for the outcome of wars: democratic initiators win more often than nondemocratic countries, and dictatorships are more likely to win wars they initiate than are mixed regimes. Democratic targets are also more successful in winning their wars $(p<.07)$. Initiators generally win the wars they start, and the military strategies included in the model have the effects anticipated by Reiter and Stam. The military and industrial capabilities ratio is positive and very significant, and not surprisingly, powerful states are usually victorious. The contributions of allies, too, are important in determining outcomes. Countries with better troops are likely to win their wars, and the choice of military strategy and the interactive effect between strategy and terrain are important.

In the bivariate test reported in column 2, the $S$ measure of satisfaction is positively related to victory in war $(p<.07)$. In the third column of Table 2 , we add the measure of a state's satisfaction with the status quo to Reiter and Stam's (2002) model. Again, the estimated coefficient is positive and even more significant $(p<.007)$. It remains significant in a model (column 4$)$ limited to the variables that identify the principal channels through which the dominant state might secure victory for itself and its allies, namely material capabilities, alliance contributions, and troop quality. The results continue to indicate that countries with alliance portfolios similar to the hegemon's are more likely to win the wars they fight, as powertransition theory predicts. 
Table 2

Logistic Regression of War Outcome, 1816-1990

\begin{tabular}{|c|c|c|c|c|c|}
\hline & $\begin{array}{c}\text { (1) } \\
\text { Outcome }\end{array}$ & $\begin{array}{c}\text { (2) } \\
\text { Outcome }\end{array}$ & $\begin{array}{c}\text { (3) } \\
\text { Outcome }\end{array}$ & $\begin{array}{c}\text { (4) } \\
\text { Outcome }\end{array}$ & $\begin{array}{c}(5) \\
\text { Outcome }\end{array}$ \\
\hline Satisfaction with status quo & & $\begin{array}{r}0.656^{\dagger} \\
(0.355)\end{array}$ & $\begin{array}{c}1.634 * * \\
(0.599)\end{array}$ & $\begin{array}{l}1.125^{*} \\
(0.471)\end{array}$ & \\
\hline Satisfaction*target & & & & & $\begin{array}{l}2.618^{* * *} \\
(0.971)\end{array}$ \\
\hline Satisfaction*initiator & & & & & $\begin{array}{c}0.799 \\
(0.771)\end{array}$ \\
\hline Poly-Pol 1*initiation & $\begin{array}{r}-6.205^{\dagger} \\
(3.387)\end{array}$ & & $\begin{array}{l}-5.676 \\
(3.573)\end{array}$ & & $\begin{array}{c}-5.829 \\
(3.598)\end{array}$ \\
\hline Poly-Pol 2*initiation & $\begin{array}{c}-1.824^{\dagger} \\
(1.037)\end{array}$ & & $\begin{array}{l}-1.717 \\
(1.110)\end{array}$ & & $\begin{array}{c}-1.727 \\
(1.106)\end{array}$ \\
\hline Politics*target & $\begin{array}{c}0.099^{\dagger} \\
(0.054)\end{array}$ & & $\begin{array}{c}0.100^{\dagger} \\
(0.059)\end{array}$ & & $\begin{array}{c}0.097 \\
(0.060)\end{array}$ \\
\hline Initiation & $\begin{array}{l}1.830^{*} \\
(0.716)\end{array}$ & & $\begin{array}{l}1.727^{*} \\
(0.744)\end{array}$ & & $\begin{array}{l}2.110 * \\
(0.852)\end{array}$ \\
\hline Capabilities & $\begin{array}{l}6.328 * * \\
(0.978)\end{array}$ & & $\begin{array}{l}6.588 * * \\
(1.039)\end{array}$ & $\begin{array}{l}3.988^{* *} \\
(0.744)\end{array}$ & $\begin{array}{l}6.490 * * \\
(1.060)\end{array}$ \\
\hline Allies' contribution & $\begin{array}{l}8.185^{* *} \\
(1.354)\end{array}$ & & $\begin{array}{l}8.868 * * \\
(1.468)\end{array}$ & $\begin{array}{l}3.691 * * * \\
(0.96)\end{array}$ & $\begin{array}{l}9.176 \text { *** } \\
(1.587)\end{array}$ \\
\hline Troop quality ratio & $\begin{array}{c}0.091^{\dagger} \\
(0.056)\end{array}$ & & $\begin{array}{c}0.084 \\
(0.056)\end{array}$ & $\begin{array}{c}0.235 \\
(0.151)\end{array}$ & $\begin{array}{c}0.088 \\
(0.060)\end{array}$ \\
\hline Terrain & $\begin{array}{c}-20.385^{* *} \\
(6.046)\end{array}$ & & $\begin{array}{c}-22.092 * * \\
(6.492)\end{array}$ & & $\begin{array}{r}-22.991 * * \\
(6.602)\end{array}$ \\
\hline Strategy*terrain & $\begin{array}{l}6.620 * * \\
(1.979)\end{array}$ & & $\begin{array}{l}7.225^{* *} \\
(2.096)\end{array}$ & & $\begin{array}{l}\text { 7.517** } \\
(2.109)\end{array}$ \\
\hline Strategy 1 & $\begin{array}{l}14.162^{*} \\
(5.850)\end{array}$ & & $\begin{array}{l}14.835^{*} \\
(6.084)\end{array}$ & & $\begin{array}{l}15.570^{* * *} \\
(6.015)\end{array}$ \\
\hline Strategy 2 & $\begin{array}{c}6.924^{\dagger} \\
(3.707)\end{array}$ & & $\begin{array}{l}7.832 * \\
(3.822)\end{array}$ & & $\begin{array}{l}8.158^{*} \\
(3.674)\end{array}$ \\
\hline Strategy 3 & $\begin{array}{c}6.609^{*} \\
(2.845)\end{array}$ & & $\begin{array}{l}7.018^{*} \\
(2.990)\end{array}$ & & $\begin{array}{l}7.375^{*} \\
(3.008)\end{array}$ \\
\hline Strategy 4 & $\begin{array}{c}5.835^{*} \\
(2.778)\end{array}$ & & $\begin{array}{l}6.018^{*} \\
(2.506)\end{array}$ & & $\begin{array}{l}6.229 * * \\
(2.411)\end{array}$ \\
\hline Constant & $\begin{array}{l}-4.306 \\
(4.700)\end{array}$ & $\begin{array}{c}-0.017 \\
(0.151)\end{array}$ & $\begin{array}{l}-5.720 \\
(5.084)\end{array}$ & $\begin{array}{l}-2.604 * * \\
(0.465)\end{array}$ & $\begin{array}{c}-6.086 \\
(5.053)\end{array}$ \\
\hline Pseudo $R^{2}$ & .52 & .01 & .54 & .25 & .55 \\
\hline Observations & 196 & 196 & 196 & 196 & 196 \\
\hline
\end{tabular}

Note: Robust standard errors in parentheses.

${ }^{\dagger}$ significant at $10 \%$. * significant at $5 \%$.** significant at $1 \%$.

It is puzzling, though, that $S$ remains so significant when the most obvious factors by which the dominant state could influence the outcome of war are included (columns 3 and 4). Power should be correlated with satisfaction, because the allies 
of the hegemon are thought to be drawn from the most powerful states. If so, the $S$ score should become less significant when the effect of national capabilities is accounted for. In fact, however, Reiter and Stam's measure of capabilities is not positively correlated with satisfaction $(r=-.05)$. A similar rationale applies to contributions from allies and troop quality. Most surprisingly, the leading state does not confer victory by creating an overwhelming coalition. The $S$ measure of satisfaction is negatively correlated with the magnitude of allied contributions $(r=-.06)$. Close association with the leading state apparently does not guarantee its active, material support in time of war. How, then, does it influence the outcome of conflict? Perhaps the hegemon is effective merely by threatening to become involved or by providing leadership that increases the effectiveness of allied contributions, but these are post hoc explanations that need investigation.

We conducted an additional test of power-transition theory using Reiter and Stam's (2002) model and data. It is designed to show whether the leading state supports initiators and defenders equally in time of war. In column 5, we add two interactive terms - satisfaction*initiator and satisfaction*target - to the baseline equation. The results indicate that the support of the hegemonic state is valuable to targets of aggression but not to initiators. These results, too, are consistent with the theory. The leading state does not support those that start wars because it prefers peace, when it can reap the benefits of the status quo (Kugler and Lemke 2000; Tammen et al. 2000, 35ff.), but it does aid allies that are attacked.

In our final set of tests, we determine whether a hegemon is able to provide private economic goods to its allies. In the first column of Table 3, we replicate Barro's (1996) analysis of economic growth, 1960 to 1990. Countries with high levels of real income grow more slowly than poorer countries ceteris paribus, and investment and human capital are positively related to growth-findings that support the theory of conditional convergence. Developing countries grow more rapidly than economically advanced countries if adequate human capital is available. Government consumption and the black market premium have negative effects, indicating that limited governmental involvement in the economy improves the prospects for development, and an increase in the terms of trade is beneficial. These results are consistent with Barro's (1991, 1996, 2000) findings.

To determine if an alliance with the leading state confers economic advantage, we first regress states' economic growth rates on the $S$ measure of satisfaction alone. The estimated coefficient is clearly insignificant $(p<.87)$. The lack of influence of the hegemon on economic outcomes is confirmed when states' satisfaction with the status quo is added to Barro's (1996) model of growth. As seen in the third column of Table 3, the sign of the estimated coefficient is negative, not positive as expected, though the estimate is insignificant $(p<.25)$. Nor is satisfaction highly correlated with the other variables in Barro's model. The conditional convergence of national incomes, which is extensively documented in the economic literature (Levine and Renelt 1992; Sala-i-Martin 1997) itself casts doubt on power-transition theory. Poor 
Table 3

OLS Regression of Economic Growth, 1960-1990

\begin{tabular}{lccc}
\hline & $(1)$ & $(2)$ & $(3)$ \\
& Growth & Growth & Growth \\
\hline Satisfaction with status quo & & -0.001 & -0.004 \\
& & $(0.003)$ & $(0.003)$ \\
Log real GDP per capita & $-0.018^{* *}$ & & $-0.017^{* *}$ \\
& $(0.003)$ & & $(0.003)$ \\
Human capital & $0.004^{*}$ & & $0.004^{*}$ \\
& $(0.002)$ & & $(0.002)$ \\
Government consumption & $-0.113^{* *}$ & & $-0.113^{* *}$ \\
& $(0.034)$ & & $(0.034)$ \\
Black market premium & $-0.007^{*}$ & & $-0.007^{*}$ \\
& $(0.003)$ & & $(0.003)$ \\
Terms of trade & $0.053^{\dagger}$ & & $0.051^{\dagger}$ \\
& $(0.027)$ & $0.027)$ \\
Investment/GDP & $0.137^{* *}$ & & $0.135^{* *}$ \\
Constant & $(0.021)$ & $(0.021)$ \\
& $0.145^{* *}$ & & $0.143^{* *}$ \\
$R^{2}$ & $(0.029)$ & .21 & .22 \\
Observations & .21 & 445 \\
\hline
\end{tabular}

Note: Robust standard errors in parentheses.

${ }^{\dagger}$ significant at $10 \%$.* significant at $5 \%$.** significant at $1 \%$.

states, not the hegemon and its powerful allies, grow most rapidly ceteris paribus. Convergence is conditional on the provision of human capital and other sound governmental policies, not on countries' ties with the leading state in the international system.

In the three tests of power-transition theory we have reported, there is convincing evidence that the hegemon is able to engineer satisfaction only in shaping the outcome of war. It does not provide peace or economic growth to its allies or deny these private goods to its rivals. Nor is it evident that the leading state itself benefits disproportionately from the status quo. The United States has been involved in militarized disputes in almost every year during the post-World War II period, and it has not had unconditional success in the wars it has fought after 1945, settling for a stalemate in both Korea and Vietnam ${ }^{12}$ and struggling, with limited support from its allies, in Iraq today. Nor do economic growth rates indicate that the international system is particularly favorable to the United States. Its average annual rate of growth, 1960 to 90 , was only slightly higher than the median (0.021 versus 0.020$)$.

It is possible, of course, that the limited support we find for power-transition theory is because of inadequacies in our measure of states' satisfaction, but using the similarity of alliance portfolios has not only been common but seems theoretically 
entailed. Power-transition theory stresses the importance of the network of defensive alliances that the leading state constructs to maintain the status quo. And if alliance portfolios are not good indicators of states' satisfaction, the results of previous research using this measure to explain the onset of war (Kim 1991, 1992; Kim and Morrow 1992; Lemke and Reed 1996), which have been taken as evidence for the theory, would have to be discounted. It is also possible that a hegemon supplies its supporters with private goods other than those we have considered, but peace and victory in war would seem to be benefits of power sine qua non, and economic growth is the source of national power (Organski 1968; Organski and Kugler 1980). Furthermore, the economic good conferred might be contingent on the character of the recipient's government (Bueno de Mesquita et al. 2003), but the principal allies of both Britain and the United States, being democracies, should be interested in broad-based economic growth.

\section{Conclusion}

A fundamental claim of power-transition theory is that world politics is characterized by hierarchy rather than anarchy. Organski (1968) compared the international system to a pyramid with the most powerful state at the apex and major, middle, and minor powers arranged in order below. Relations among these states are thought to reveal important patterns in the distribution of value. The dominant state benefits disproportionately, but it also "orders, adjusts, and allocates" private goods to others (Siverson and Miller 1996, 59), managing the international system for the benefit of its allies and to the detriment of potential rivals. Here, we have assessed the ability of the leading state to engineer satisfaction in the international system through the distribution of three private benefits: peace, victory in war, and prosperity. To test the theory, we added a measure of the similarity of a state's portfolio of alliances to the hegemon's (Signorino and Ritter 1999) to models of the initiation of fatal militarized disputes (Oneal 2006), the outcome of wars (Reiter and Stam 2002), and economic growth in per capita income (Barro 1996).

We found only limited support for power-transition theory. Being closely allied to the leading state does not protect a country from being the target of attack-results that are consistent with earlier tests of power-transition theory reported by Russett and Oneal (2001) and Bennett and Stam (2004). Nor does close association with the leading state increase the prospects for economic success. We did find convincing statistical evidence that the dominant power helps its allies win the wars they fight, an important benefit to be sure, but the means by which the leading state affects this result is unclear. Surprisingly, material contributions by the leader to its allies' war efforts are not a mechanism. As theoretically expected, the support of the leading state is important to allies that are targets of attack but not to those that initiate a war. Finally, it is not evident that the hegemon itself benefits disproportionately 
from the international system. The United States after World War II has not been particularly peaceful, victorious, or successful economically. On balance, our results call into question the ability of the leading state to provide private goods to itself, distribute them to allies, or withhold them from rivals.

There is a great deal of evidence that, as power-transition theory claims, a preponderance of power makes peace at the dyadic level more likely. We find little indication, however, that the leading state is able to extend the benefit of its great power to others by managing and directing the international system through the provision of private goods. As noted earlier, previous assessments of hegemonic-stability theory have produced mixed results regarding the leading state's ability to supply international public goods. Thus, both power-transition theory and hegemonicstability theory exaggerate the influence of the leading state in the international system-a result with important implications in the contemporary post-cold war era.

\section{Notes}

1. Power-transition theorists avoid the term hegemon (Tammen et al. 2000, 6), but they speak freely of "the international system as a hierarchy dominated by one power, the strongest state in the system" (Lemke 2004). We use hegemon for stylistic reasons to denote this dominant state.

2. The correlation expected between power and satisfaction is shown in Tammen et al.'s (2000, 10) diagrammatic representation of the distribution of satisfaction. Organski (1968, 369), who was the source of this figure, noted that "power and satisfaction do not go hand in hand, although they are related." States can be powerful and dissatisfied, but most powerful states should be satisfied because of their value as allies; however, Lemke and Reed (1998), using Granger causality tests, find no relationship between states' power and their evaluation of the status quo, 1816 to 1985 . This result strikes at the core of traditional realism and power-transition theory, both of which assume that powerful states use their capabilities successfully to promote their interests.

3. Emphasis on the danger of power parity alone is inconsistent with the argument and evidence presented in Organski and Kugler (1980), as DiCicco and Levy (1999, 2003) note.

4. Organski and Kugler (1980, 38-61) noted that it is necessary to measure the satisfaction of states to evaluate power-transition theory and proposed a measure based on the tightening or loosening of alliances. In the discussion that follows, however, they refer to this as an indicator of leaders' perceptions of threat or willingness to fight, not satisfaction per se. In any event, change in the alliance structure was not significantly related in their tests to the onset of wars between the dominant nation and its contenders.

5. The use of alliance portfolios to measure satisfaction is not unproblematic, however. It assumes that alliances are sincere expressions of states' preferences (Kugler and Lemke 2000); Siverson and Miller (1996) note some anomalous cases. Lemke $(2002,101)$ suggests that the similarity of alliances may not discriminate adequately among minor powers, but the theory holds that most small states will be dissatisfied because they are unimportant to the hegemon's efforts to maintain the status quo (Organski 1968; Tammen et al. 2000, 10). There is also the danger that the pattern of alliances is endogenous: past conflict may influence both the current system of alliances and the present likelihood of conflict.

6. A state is a coherent democracy if its democracy score minus its autocracy score is greater than 6; it is a coherent autocracy if the net score is less than -6 . Mixed or incoherent regimes have both democratic and autocratic qualities; their scores range from -6 to +6 .

7. Oneal (2006; Oneal and Tir 2006) finds no evidence of an autocratic peace or the importance of political similarity generally. The probability that an autocratic state will initiate a fatal dispute against another autocracy is not significantly different from the odds that any of the other five dyads 
whose coefficients were insignificant will experience an initiation (Bueno de Mesquita and Ray 2004; Bennett 2006; cf. Werner 2000; Henderson 2002; and Peceny, Beer, and Sanchez-Terry 2002).

8. Empirical tests do not support unconditional convergence but provide evidence for conditional convergence; countries with initially lower per capita income have a faster growth rate in per capita income only if other factors (namely, education and other elements of human capital) are taken into account (Barro 1991; Levine and Renelt 1992; Sala-i-Martin 1997).

9. We also conducted monadic analyses of states' involvement in militarized disputes based on Maoz (1996) and Bussmann (2001) but again found no evidence that being allied to the hegemon increases a state's prospects for peace.

10. The results reported in column 4 change only minimally if Allies is dropped from the regression model.

11. Reiter and Stam's (2002) analysis contains 197 observations, but there is no $S$ score in the COW data for one case (Bulgaria, 1885), because Bulgaria was not recognized as an independent nation until 1908. In column 1, we report the estimated coefficients obtained with 196 cases to facilitate comparison with those with the measure of satisfaction added. There are only slight differences between these results and Reiter and Stam's.

12. Neither war is included in our analysis of war outcomes because Reiter and Stam (2002) code these conflicts as draws, so they are dropped from the sample. The United Kingdom fared better, winning all its wars (Crimean War, Anglo-Persian War, Boxer Rebellion, and the two World Wars).

\section{References}

Barro, R. J. 1989. A cross-country study of growth, saving, and government. NBER Working Paper No. 2855. Cambridge, MA: National Bureau of Economic Research.

1991. Economic growth in a cross section of countries. The Quarterly Journal of Economics 56:407-43.

1996. Democracy and growth. Journal of Economic Growth 1:1-27.

2000. Inequality and growth in a panel of countries. Journal of Economic Growth 5:5-32.

Barro, R., and J.-W. Lee. 1994. Data set for a panel of 138 countries. Cambridge, MA: National Bureau of Economic Research.

Beck, N., J. N. Katz, and R. Tucker 1998. Taking time seriously in binary time-series-cross-section analysis. American Journal of Political Science 42:1260-88.

Bennett, D. S. 2006. Toward a continuous specification of the democracy-autocracy connection. International Studies Quarterly 50 (2): 313-38.

Bennett, D. S., and A. Stam. 2000. EUGene: A conceptual manual. International Interactions 26:179-204. Version 3.04. http://eugenesoftware.org. 2004. The behavioral origins of war. Ann Arbor: University of Michigan Press.

Boulding, K. E. 1963. Conflict and defense. New York: Harper and Row.

Bueno de Mesquita, B. 1981. The war trap. New Haven, CT: Yale University Press. 1990. Pride of Place: The Origins of Germany Hegemony. World Politics 43:28-52.

1996. Beliefs about power and the risks of war: A power transition game. In Parity and war: Evaluations and extensions of The War Ledger, edited by J. Kugler and D. Lemke, 271-86. Ann Arbor: University of Michigan Press.

Bueno de Mesquita, B., and J. L. Ray. 2004. The national interest versus individual political ambition: Democracy, autocracy, and the reciprocation of force and violence in militarized interstate disputes. In The scourge of war: New extensions of an old problem, edited by P. Diehl, 94-119. Ann Arbor: University of Michigan Press.

Bueno de Mesquita, B., A. Smith, R. M. Siverson, and J. D. Morrow. 2003. The logic of political survival. Cambridge, MA: MIT Press. 
Bussmann, M. 2001. Examining causality among militarized interstate disputes, regime type, trade openness, and economic growth. PhD diss. University of Alabama, Tuscaloosa.

de Soysa, I., and J. R. Oneal. 1999. Boon or bane? Reassessing the productivity of foreign direct investment. American Sociological Review 64:766-82.

de Soysa, I., J. R. Oneal, and Y.-H. Park. 1997. Testing power-transition theory using alternative measures of national capabilities. Journal of Conflict Resolution 41:509-28.

DiCicco, J. M., and J. S. Levy. 1999. Power shifts and problem shifts: The evolution of the power transition research program. Journal of Conflict Resolution 43:675-704.

— 2003. The power transition research program. In Progress in International Relations Theory: Appraising the Field, edited by C. Elman and M. F. Elman, 109-57. Cambridge, MA: MIT Press.

Epstein, M., ed. 1913. The statesman's yearbook, 1913. London: Macmillan.

Geller, D. 1992. Power transition and conflict initiation. Conflict Management and Peace Science 12:1-16.

Gilpin, R. 1981. War and change in world politics. Cambridge, UK: Cambridge University Press.

Gleditsch, K. S. 2002. Expanded trade and GDP data version 1. Journal of Conflict Resolution 46: $712-24$.

Hegre, H. 2004. Size asymmetry, trade, and militarized conflict. Journal of Conflict Resolution 48: 403-29.

Henderson, E. A. 2002. Democracy and war: The end of an illusion? Boulder, CO: Lynne Rienner.

Jaggers, K., and T. R. Gurr. 1995. Tracking democracy's third wave with the Polity III data. Journal of Peace Research 32:469-82.

Kadera, K. M. 2001. The power-conflict story: A dynamic model of interstate rivalry. Ann Arbor: University of Michigan Press.

Kennedy, P. 1988. The rise and fall of the great powers. New York: Random House.

Keohane, R. O. 1980. The theory of hegemonic stability and changes in international economic regimes, 1967-1977. In Changes in the international system, edited by O. Holsti, R. Siverson, and A. George, 131-62. Boulder, CO: Westview.

1984. After hegemony: Cooperation and discord in the world political economy. Princeton, NJ: Princeton University Press.

Kim, W. 1991. Alliance transitions and great power war. American Journal of Political Science 35:83350.

1992. Power transitions and great power war from Westphalia to Waterloo. World Politics 45:153-72.

Kim, W. 1996. Power parity, alliance, and war from 1648 to 1975. In Parity and war, edited by J. Kugler and D. Lemke, 93-106. Ann Arbor: University of Michigan Press.

Kim, W., and J. Morrow. 1992. When do power shifts lead to war? American Journal of Political Science 36:896-922.

King, G. 1991. "Truth" is stranger than prediction, more questionable than causal inference. American Journal of Political Science 35 (4): 1047-53.

Kindleberger, C. 1973. The world in depression, 1929-1939. Los Angeles: University of California Press.

Krasner, S. 1976. State power and the structure of international trade. World Politics 28:317-47.

Kugler, J., and D. Lemke, eds. 1996. Parity and war: Evaluations and extensions of The War Ledger. Ann Arbor: University of Michigan Press.

Kugler, J., and D. Lemke 2000. The power transition research program. In Handbook of war studies, 2nd ed., edited by M. I. Midlarsky, 129-63. Ann Arbor: University of Michigan Press.

Lemke, D. 2002. Regions of war and peace. Cambridge, UK: Cambridge University Press.

2004. Great powers in the post-cold war world: A power transition perspective. In Balance of power: Theory and practice in the 21 st century, edited by T. V. Paul, J. J. Wirtz, and M. Fortmann, 52-75. Stanford, CA: Stanford University Press. 
Lemke, D., and J. Kugler. 1996. The evolution of the power transition perspective. In Parity and war, edited by J. Kugler and D. Lemke, 3-34. Ann Arbor: University of Michigan Press.

Lemke, D., and W. Reed. 1996. Regime types and status quo evaluations: Power transition theory and the democratic peace. International Interactions 22:143-64.

. 1998. Power is not satisfaction. Journal of Conflict Resolution 42:511-16.

Lemke, D., and S. Werner. 1996. Power parity, commitment to change, and war. International Studies Quarterly 40:235-60.

Levine, R., and D. Renelt. 1992. A sensitivity analysis of cross-country growth regressions. The American economic review 82:942-63.

Lucas, R. E. Jr. 1988. On the mechanics of economic development. Journal of Monetary Economics 22:3-42.

Maddison, A. 1995. Monitoring the world economy: 1820-1992. Paris: Organization for Economic Cooperation and Development.

Mansfield, E. 1994. Power, trade, and war. Princeton, NJ: Princeton University Press.

Mansfield, E., and B. Pollins, eds. 2003. Economic interdependence and international conflict: New perspectives on an enduring debate. Ann Arbor: University of Michigan Press.

Maoz, Z. 1996. Domestic sources of global change. Ann Arbor: University of Michigan Press.

1999. Dyadic militarized interstate disputes (DYMID1.1). Dataset-Version 1.1. ftp://spirit.tau.ac.il/zeevmaos/dyadmid60.xls. August.

Olson, M., 1971. The logic of collective action: Public goods and the theory of groups. Cambridge, MA: Harvard University Press.

Oneal, J. R. 2006. Confirming the liberal peace with analyses of directed dyads, 1885-2001. In Approaches, levels, and methods of analysis in international politics: Crossing boundaries, edited by Harvey Starr, 73-94. New York: Palgrave Macmillan.

Oneal, J. R., I. de Soysa, and Y.-H. Park. 1998. But power and wealth are satisfying: A reply to Lemke and Reed. Journal of Conflict Resolution 42:517.

Oneal, J. R., and P. F. Diehl. 1994. The theory of collective action and NATO defense burdens: New empirical tests. Political Research Quarterly 48:373-96.

Oneal, J. R., and B. Russett. 1997. The classical liberals were right: Democracy, interdependence, and conflict, 1950-1985. International Studies Quarterly 41:267-94.

Oneal, J. R., and B. Russett 2005. Rule of three, let it be? When more really is better. Conflict Management and Peace Science 22 (4): 293-310.

Oneal, J. R., B. Russett, and M. L. Berbaum. 2003. Causes of peace: Democracy, interdependence, and international organizations, 1885-1992. International Studies Quarterly 47:371-93.

Oneal, J. R., and J. Tir. 2006. Does the diversionary use of force threaten the democratic peace? Assessing the effect of economic growth on interstate conflict, 1921-2001. International Studies Quarterly 50: 755-79.

Organski, A. F. K. 1968. World politics. 2nd ed. New York: Knopf.

Organski, A. F. K., and J. Kugler. 1980. The War Ledger. Chicago: University of Chicago Press.

Peceny, M., C. C. Beer, and S. Sanchez-Terry. 2002. Dictatorial peace? American Political Science Review 96:15-26.

Peet, C. 1992. Declining hegemony and rising international trade: Moving beyond hegemonic stability theory. International Interactions 18:101-27.

Pollins, B. M. 1996. Global political order, economic change, and armed conflict: Coevolving systems and the use of force. American Political Science Review 90:103-17.

Raknerud, A. and H. Hegre. 1997. The hazard of war: Reassessing the evidence for the democratic peace. Journal of Peace Research 34:385-404.

Ray, J. L. 2005. Constructing multivariate analyses (of dangerous dyads). Conflict Management and Peace Science 22 (4): 277-92. 
Reed, W. 2003. Information, power, and war. American Political Science Review 97:633-42.

Reiter, D., and A. C. Stam. 2002. Democracies at war. Princeton, NJ: Princeton University Press.

Romer, P. M. 1990. Endogenous technological change. Journal of Political Economy 98:71-102.

Russett, B. 1985. The mysterious case of vanishing hegemony; or, is Mark Twain really dead? International Organization 39:207-31.

Russett, B., and J. R. Oneal. 2001. Triangulating peace: Democracy, interdependence, and international organizations. New York: Norton.

Sacko, D. 2003. Hegemonic governance and the process of conflict. PhD diss. Pennsylvania State University, University Park.

Sala-i-Martin, Xavier. 1997. I just ran two million regressions. American Economic Review 87 (2): 178-83.

Sandler, T., and K. Hartley, eds. 1999. The political economy of NATO: Past, present, and into the 21st century. Cambridge, UK: Cambridge University Press.

Schneider, G., K. Barbieri, and N. P. Gleditsch, eds. 2003. Globalization and armed conflict. Boulder, CO: Rowan and Littlefield.

Senese, P. D., and J. Vasquez. 2005. Assessing the steps to war. British Journal of Political Science 35 : 607-33.

Signorino, C. S., and J. M. Ritter. 1999. Tau-b or not tau-b: Measuring the similarity of foreign policy positions. International Studies Quarterly 43:115-44.

Siverson, R. M., and R. A. Miller. 1996. The power transition: Problems and prospects. In Parity and war, edited by J. Kugler and D. Lemke, 57-76. Ann Arbor: University of Michigan Press.

Snidal, D. 1985. The limits of hegemonic stability theory. International Organization 39:579-614.

Solow, R. M. 1956. A contribution to the theory of economic growth. Quarterly Journal of Economics 70:65-94.

Spiezio, K. E. 1990. British hegemony and major power wars, 1815-1939: An empirical test of Gilpin's model of hegemonic governance. International Studies Quarterly 34:165-81.

Starr, H. 1978. "Opportunity" and "willingness" as ordering concepts in the study of war. International Interactions 4:363-87.

Stinnett, D., J. Tir, P. Shafer, P. Diehl, and C. Gochman. 2002. The Correlates of War project direct contiguity data. Conflict Management and Peace Science 19:59-67.

Sweeney, K. J. 2003. Are dyadic capability preponderances really more pacific? Journal of Conflict Resolution 47:728-50.

Tammen, R. L., J. Kugler, D. Lemke, A. C. Stam III, M. Abdollahian, C. Alsharabati, B. Efird, and A. F. K. Organski. 2000. Power transitions: Strategies for the 21st century. New York: Chatham House.

Tucker, R. 1999. BTSCS: A binary time-series-cross-section data analysis utility. Version 4.0.4. Cambridge, MA: Harvard University. http://www.fas.harvard.edu/ rtucker/programs/ btscs/btscs.html (accessed November, 16, 2002).

Vasquez, J. 1993. The war puzzle. Cambridge, UK: Cambridge University Press.

- 1996. When are power transitions dangerous?" In Parity and war, edited by J. Kugler and D. Lemke, 35-56. Ann Arbor: University of Michigan Press.

Webb, M. C., and Krasner, S. 1989. Hegemonic stability theory: An empirical assessment. Review of International Studies 15:183-98.

Werner, S. 2000. The effects of political similarity on the onset of militarized disputes, 1816-1985. Political Research Quarterly 53:343-74.

Werner, S., and J. Kugler. 1996. Power transitions and military buildups: Resolving the relationship between arms buildups and war. In Parity and war, edited by J. Kugler and D. Lemke, 187-210. Ann Arbor: University of Michigan Press. 